\title{
Net Sales Cost of Goods Sold Other Expense Dan Income Tax Expense-Net Atas Output Laba Bersih (Case Study)
}

\author{
Cahyadi Husada ${ }^{1, *}$, Pratiwi Nila Sari ${ }^{1}$, Ery Teguh Prasetyo ${ }^{1}$ \\ ${ }^{1}$ Fakultas Ekonomi dan Bisnis Manajemen; Universitas Bhayangkara Jakarta Raya; Jl. \\ Harsono Rm Dalam No.46, RT.7/RW.4, Ragunan, Kec. Ps. Minggu, Kota Jakarta Selatan, \\ Daerah Khusus Ibukota Jakarta 12550; e-mail: cahyadi.husadha@dsn.ubharajaya.ac.id, \\ pratiwi@ubharajaya.ac.id, ery.teguh@ubharajaya.ac.id \\ * Korespondensi: e-mail: cahyadi.husadha@dsn.ubharajaya.ac.id
}

Submitted: 08/10/2020; Revised: 02/12/2020; Accepted: 07/12/2020; Published: 15/01/2021

\begin{abstract}
This study aims to determine the specific influence between the independent variables and the dependent variable either partially or simultaneously. This study was conducted to analyze previous research with similar research objects at the Food \& beverages Sub-Sector Companies listed on the Indonesia Stock Exchange. This is done in order to match accounting theory and practice that is applied properly and correctly in other forms of business that have a mission to improve financial performance such as these companies on the IDX. The method in this research is quantitative statistics with a probability sample in the form of purposive sampling. The stages are to determine the population and sample independently, and then process them using a data processing tool called Eviews version 9 to the classical assumption test and hypothesis testing. The results obtained partially for the Net Sales hypothesis test $(x 1)$ has no effect because it has a probability value of 0.3497, for Cost of Goods Sold (x2) has an effect because it has a probability value of 0.000, for Other Expenses (x3) has an effect because it has a value probability of 0.000, and for Net Tax Expense (x4) has an effect because it has a probability value of 0.000. Meanwhile, simultaneously, Net Sales (x1), Cost of Goods Sold (x2), Other Expenses (x3), Net Tax Expenses (x4) have an effect. This can be seen in the table above which shows the Prob F-statistic of 0.000000.
\end{abstract}

Keywords: Net Sales, Cost Of Goods Sold, Other Expense, Income Tax Expense-Net, Net Income

\begin{abstract}
Abstrak
Penelitian ini bertujuan untuk mengetahui spesifik adanya pengaruh antar variabel independen dengan dari variabel dependen baik secara parsial maupun simultan. Penelitian ini dilakukan untuk menganalisis penelitian terdahulu dengan objek penelitian yang serupa pada Perusahaan Sub Sektor Food \& beverages yang terdaftar di Bursa Efek Indonesia. Hal tersebut dilakukan guna mencocokkan antara teori dan praktik akuntansi yang diterapkan secara baik dan benar pada bentuk usaha lainnya yang memiliki misi dalam peningkatan kinerja keuangan seperti perusahaan tersebut di BEI. Metode dalam penelitian ini adalah statistik kuantitatif dengan sampel probabilitas berupa purposive sampling. Tahapannya adalah dengan menentukan populasi dan sampel secara bebas, dan kemudian mengolahnya menggunakan alat pengolahan data bernama eviews versi 9 sampai kepada uji asumsi klasik dan pengujian hipotesis. Hasil penelitian didapat secara parsial untuk uji hipotesis Penjualan Bersih (x1) tidak memiliki pengaruh karena memiliki nilai probabilitas sebesar 0.3497, untuk Beban Pokok Penjualan (x2) memiliki pengaruh karena memiliki nilai probabilitas sebesar 0.000, untuk Beban Lainnya $(x 3)$ memiliki pengaruh karena memiliki nilai probabilitas sebesar 0.000 , dan untuk Beban Pajak Bersih (x4) memiliki pengaruh karena memiliki nilai probabilitas sebesar 0.000 .
\end{abstract}


Sedangkan secara simultan, Penjualan Bersih (x1), Beban Pokok Penjualan (x2), Beban Lainnya (x3), Beban Pajak Bersih (x4) mempunyai pengaruh. Hal ini dapat dilihat pada tabel diatas yang menunjukkan Prob F-statistiknya sebesara 0.000000 .

Kata kunci: Penjualan Bersih, Harga Pokok Penjualan, Beban Lainnya, Beban Pajak Penghasilan-Bersih, Laba Bersih

\section{Pendahuluan}

Bursa Efek Indonesia mempublikasikan banyak laporan keuangan ke khalayak publik sebagai bentuk pertanggung-jawabannya terhadap usaha dijalankan sampai pada tahun 2019, sekaligus sebagai sarana pembelajaran masyarakat terhadap pembelajaran akuntansi secara khusus, serta wujud dari bentuk transparansi keuangan yang menjadi komponen dari pengelolaan tata pengaturan yang baik secara umum. Pada kenyataanya, perusahaan dalam penyelesaian siklus akuntansinya pun tidak pernah luput dari beberapa komponen yang diketahui khalayak publik. Khususnya para akuntan untuk konsep teori akuntansi yang berlaku umum bagi setiap orang. Berikut gambaran tersebut; 1.) kegiatan usaha tidak melakukan produksi, melainkan pemberian label perusahaan, 2.) perusahaan memiliki jenis usaha dan kegiatan usahanya dilakukan dengan Cara jual-beli, konsinyasi, kontrak, dan lainnya atas pesediaan barang dagangannya, 3.) kegiatan promosi usahanya memunculkan utang-piutang, seperti dalam hal pembelian dan penjualan secara kredit, 4.) selalu terlibat dalam pembayaran pajak yang berkelanjutan, 5.) fokus akuntansi secara sebagian terdapat pada Jurnal Khusus, pengelolaan persediaan barang dagangan, menyelesaikan siklus akuntansi dagang, dan sebagainya, 6.) dalam perhitunganya memunculkan Harga Pokok Penjualan.

Perusahaan dagang adalah keseluruhan perbuatan dilakukan secara terus-menerus, bertindak keluar, dan memperoleh penghasilan dengan mendagangkan produksi yang dikerjakan dalam sebuah perusahaan dagang. Perusahaan dagang juga merupakan sebuah bisnis yang berbentuk perusahaan dagang yang mendapatkan keuntungan dari kegiatan yang dilakukan dalam perusahaan dagang itu. Sehingga dapat dikatakan bahwa perusahaan dagang yang membuat sebuah produksi, dan mengelola sumber daya menjadi sebuah bahan untuk membuat produk yang didistribusikan pada konsumen (www.pelajaran.co.id, 2019).

Bursa Efek Indonesia memberikan kategori-kategori untuk perusahaan manufaktur menjadi sektor dan subsektor. Ada tiga sektor utama manufaktur, yakni sektor industri dasar dan kimia, sektor industri barang konsumsi, dan sektor aneka industri. Sub-sektornya sendiri terbagi hingga 20. Selain subsektor kosmetik keperluan rumah tangga, industri barang konsumsi juga memiliki subsektor makanan dan minuman (Andhika, 2020).

Laporan keuangan merupakan hasil akhir dari pekerjaan akuntansi secara menyeluruh. Penyusunan laporan keuangan juga harus dilaporkan dalam urutan sistematis seperti berikut ini: 1) Laporan laba-rugi; 2) Laporan Ekuitas Pemilik; 3) Laporan Neraca; 4) Laporan Arus Kas. (Husadha, C., Zen, A., \& Panjaitan, 2014). Laporan keuangan merupakan salah satu pertanggung-jawaban Manajemen kepada pihak principal (investor, pemilik dana untuk 
melaporkan hasil/kinerja yang telah dilakukan sepanjang periode) (Mahmudah, Suryati, \& Husadha, 2019).

Harahap (2007:296) mengemukakan bahwa informasi penting dalam suatu laporan keuangan adalah laba. Kegunaan laba yaitu: 1) Untuk menghitung pajak, digunakan sebagai dasar penerimaan pajak Negara; 2) Menghitung jumlah deviden yang akan dibagikan dan yang akan ditahan perusahaan; 3). Sebagai pedoman dalam pengambilan keputusan dan menentukan kebijakan investasi; 4) Menjadi alat meramalan laba maupun kejadian ekonomi perusahaan lainnya dimasa yang akan dating; 5) Menilai efesiensi perusahaan; dan 6) Mengukur kinerja/prestasi perusahaan (Nurlita, Nugroho, \& Ainiyah, 2017).

Beban (expenses) adalah penurunan manfaat ekonomi selama satu periode akuntansi dalam bentuk arus keluar/berkurangnya aset/terjadinya liabilitas yang mengakibatkan penurunan ekuitas yang tidak menyangkut pembagian kepada penanam modal. Definisi beban mencakup baik beban yang timbul dalam pelaksanaan aktivitas perusahaan yang biasa maupun kerugian (loss). Biaya yang dikorbankan (dikonsumsi) dalam rangka memperoleh pendapatan (revenues) dalam suatu periode akuntansi (Hapsari \& Saputra, 2018).

Beban pokok penjualan juga dapat disebut sebagai Harga pokok Penjualan (HPP). HPP adalah jumlah biaya produksi yang melekat pada persediaan barang jadi sebelum barang tersebut laku dijual. HPP = biaya produksi apabila tidak ada persediaan produk dalam proses awal dan akhir. Biaya produksi periode berjalan disesuaikan dengan persediaan barang dalam proses pada awal dan akhir periode. HPP termasuk bagian dari cost, merupakan pengeluaran untuk mendapatkan manfaat dari barang/produk yang dibeli dan manfaat tersebut belum terjadi/belum diterima (Satwika, Hendratno, \& Zultilisna, 2018).

Beban pajak penghasilan bersih disebut sebagai pajak penghasilan dari wajib pajak badan dan perseorangan. Beban pajak (penghasilan pajak) menurut PSAK 46 (Pernyataan Standar Akuntansi Keuangan 46)/ IAS 12 (International Accounting Standard 12); adalah jumlah gabungan pajak kini dan pajak tangguhan yang diperhitungkan dalam menentukan laba-rugi pada suatu periode. Beban pajak (penghasilan pajak) terdiri dari beban pajak kini (penghasilan pajak kini) dan beban pajak tangguhan (penghasilan pajak tangguhan). Beban pajak tangguhan (penghasilan pajak tangguhan) itu, terjadi sebagai akibat dari pengakuan liabilitas pajak tangguhan (aset pajak tangguhan) di laporan posisi keuangan (W. W. Hidayat, Purnomo, \& Ulfah, 2016).

Penjualan barang meliputi barang yang diproduksi perusahaan untuk dijual dan barang yang dibeli untuk dijual kembali seperti barang yang dibeli pengecer/tanah/properti lain yang dibeli untuk dijual kembali. Penjualan jasa biasanya menyangkut pelaksanaan tugas yang secara kontraktual telah disepakati untuk dilaksanakan selama satu periode yang disepakati oleh perusahaan, jasa tersebut dapat diserahkan selama satu periode/lebih selama lebih dari satu periode (Kurniawan, Hidayati, \& Cholifah, 2016). Harga jual harus bisa menutupi hal-hal sebagai berikut: (a). Harga pokok barang yang dijual, (b). Biaya operasi, yang terdiri dari biaya pemasaran dan biaya administrasi dan umum, seperti biaya gaji, biaya sewa, biaya asuransi, 
biaya komisi penjualan, biaya promosi, dan lain-lain. (c). Laba yang diinginkan oleh perusahaan. Penjualan bersih adalah hasil penjualan bruto/ kotor sesudah dikurangi dengan berbagai potongan serta pengurangan lainnya, seperti; diskon penjualan, dan retur penjualan. Sujarweni melanjutkan, bahwa; Penjualan dalam peusahaan dagang sebagai salah satu unsur dari pendapatan perusahaan. Penjualan bersih meliputi Penjualan kotor dikurangi Retur pejualan dan dikurangi Potongan penjualan. (W. W. Hidayat et al., 2016).

\section{Metode Penelitian}

Desain penelitian adalah pedoman atau prosedur serta teknik dalam perencanaan penelitian yang berguna sebagai panduan untuk membangun strategi yang menghasilkan model atau blue print penelitian (Aprillia Susanti, 2018). Desain penelitian ini menggunakan deskriptif kuantitatif. Statistik deskriptif artinya menggambarkan berbagai karakteristik data berasal dari suatu sampel. Penelitian dengan pendekatan kuantitatif berarti penelitian dengan penekanan pada pengujian teori melalui pengukuran variabel-variabel penelitian angka dan melakukan analisis data dengan prosedur statistik. Menggambarkan suatu fenomena dengan memaparkan sejumlah variabel yang berkenaan dengan masalah yang diteliti.

Model konseptual penelti dengan judul penelitian: "Pengaruh Net Sales, Cost of Goods Sold, Other Expense, dan Income Tax Expense-Net Terhadap Output Laba Bersih (Studi Kasus Perusahaan Sub Sektor Food \& beverages yang Terdaftar di BEI)" dapat dilihat pada gambar berikut.

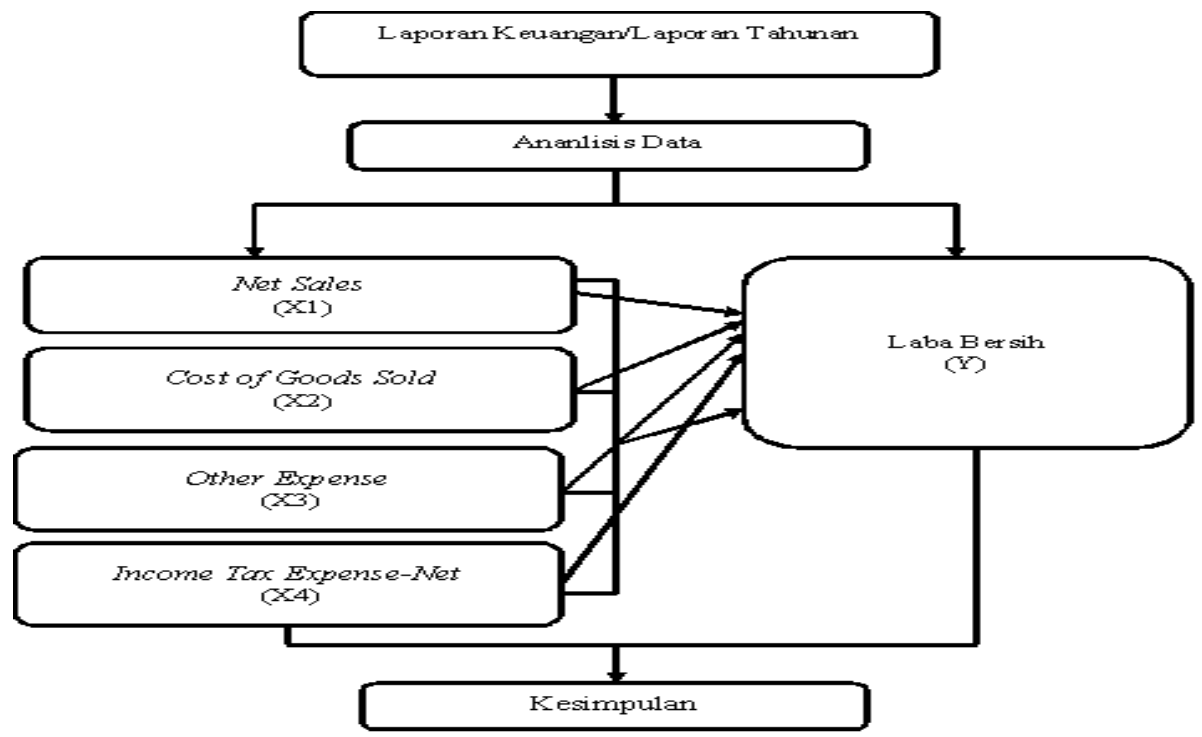

Sumber: Hasil Penelitian (2020)

Gambar 1. Model Konseptual

Penelitian ini dilaksanakan di Bursa Efek Indonesia (BEI), peneliti memanfaatkan fasilitas web seperti; $\underline{w w w . i d x . c o . i d ~ d a n ~ w e b ~ p e r u s a h a a n ~ l a n s u n g ~ y a n g ~ t i d a k ~ d a p a t ~ p e n e l i t i ~}$ uraikan satupersatu, namun tetap dapat mendukung peneliti dalam mencari data penelitian. Peneliti mendapatkan data perusahaan Sub Sektor Food \& beverages di BEI dengan penyajian tabel 1. 
Tabel 1. Daftar Perusahaan Sub Sektor Food \& beverages

\begin{tabular}{|l|l|l|l|}
\hline No & Kode & Nama Emiten & Tanggal Pencatatan \\
\hline 1 & ADES & Akasha Wira International Tbk & $13 / 06 / 1994$ \\
\hline 2 & AISA & Tiga Pilar Sejahtera Food Tbk & $11 / 06 / 1997$ \\
\hline 3 & ALTO & Tri Banyan Tirta Tbk & $10 / 07 / 2012$ \\
\hline 4 & BTEK & Bumi Teknokultura Unggul Tbk & $14 / 05 / 2004$ \\
\hline 5 & BUDI & Budi Starch \& Sweetener Tbk & $08 / 05 / 1995$ \\
\hline 6 & CAMP & Campina Ice Cream Industry Tbk & $19 / 12 / 2017$ \\
\hline 7 & CEKA & Wilmar Cahaya Indonesia Tbk & $09 / 07 / 1996$ \\
\hline 8 & CLEO & Sariguna Primatirta Tbk & $05 / 05 / 2017$ \\
\hline 9 & DLTA & Delta Djakarta Tbk & $12 / 02 / 1984$ \\
\hline 10 & FOOD & Sentra Food Indonesia Tbk & $08 / 01 / 2019$ \\
\hline 11 & GOOD & Garudafood Putra Putri Jaya Tbk & $10 / 10 / 2018$ \\
\hline 12 & HOKI & Buyung Poetra Sembada Tbk & $22 / 06 / 2017$ \\
\hline 13 & ICBP & Indofood CBP Sukses Makmur Tbk & $07 / 10 / 2010$ \\
\hline 14 & IIKP & Inti Agri Resources Tbk & $20 / 10 / 2002$ \\
\hline 15 & INDF & Indofood Sukses Makmur Tbk & $14 / 07 / 1994$ \\
\hline 16 & MGNA & Magna Investama Mandiri Tbk & $07 / 07 / 2014$ \\
\hline 17 & MLBI & Multi Bintang Indonesia Tbk & $17 / 01 / 1994$ \\
\hline 18 & MYOR & Mayora Indah Tbk & $04 / 07 / 1990$ \\
\hline 19 & PANI & Pratama Abadi Nusa Industri Tbk & $18 / 09 / 2018$ \\
\hline 20 & PCAR & Prima Cakrawala Abadi Tbk & $29 / 12 / 2017$ \\
\hline 21 & PSDN & Prasidha Aneka Niaga Tbk & $18 / 10 / 1994$ \\
\hline 22 & ROTI & Nippon Indosari Corpindo Tbk & $28 / 06 / 2010$ \\
\hline 23 & SKBM & Sekar Bumi Tbk & $05 / 01 / 1993$ \\
\hline 24 & SKLT & Sekar Laut Tbk & $08 / 09 / 1993$ \\
\hline 25 & STTP & Siantar Top Tbk & $16 / 12 / 1996$ \\
\hline 26 & ULTJ & Ultra Jaya Milk Industry \& Trading Company Tbk & $02 / 07 / 1990$ \\
\hline & & \\
\hline & & \\
\hline & & \\
\hline
\end{tabular}

Sumber : (Andhika, 2020)

Analisis kualitatif penelitian dilakukan melalui metode deskriptif (Trend Analysis). Adapun analisis Statistik dalam penelitian ini adalah dengan analisis regresi. Analisis regresi dimaksud adalah studi dari satu variabel dependent terhadap satu atau lebih variabel independent. Hal ini dilakukan dengan tujuan agar dapat memperkirakan atau meramalkan nilai rata-rata dari variabel berikut; Laba Bersih (Y), Net Sales (X1), Cost of Goods Sold (X2), Other Expense (X3), dan Income Tax Expense-Net (X4).

Hipotesis dalam penelitian ini adalah sebagai berikut:

Ha1 : Net Sales berpengaruh terhadap Laba Bersih.

Ho1 : Net Sales tidak berpengaruh terhadap Laba Bersih.

Ha2 : Cost of Goods Sold berpengaruh terhadap Laba Bersih.

Ho2 : Cost of Goods Sold tidak berpengaruh positif terhadap Laba Bersih.

Ha3 : Other Expense berpengaruh terhadap Laba Bersih.

Ho3 : Other Expense tidak berpengaruh terhadap Laba Bersih.

Ha4 : Income Tax Expense-Net berpengaruh terhadap Laba Bersih.

Ho4 : Income Tax Expense-Net tidak berpengaruh terhadap Laba Bersih.

Ha5 : Net Sales, Cost of Goods Sold, Other Expense, dan Income Tax Expense-Net secara bersama-sama berpengaruh terhadap Laba Bersih. 
Ho5 : Net Sales, Cost of Goods Sold, Other Expense, dan Income Tax Expense-Net secara bersama-sama tidak berpengaruh terhadap Laba Bersih.

\section{Hasil dan Pembahasan}

Diantara berbagai metode regresi, regresi data panel merupakan salah satu teknik regresi yang memiliki kelebihan tersendiri dibandingkan teknik lainnya karena menawarkan berbagai model estimasi. Terdapat beberapa tahapan dalam analisis regresi data penel yaitu pemilihan model regresi, pengujian asumsi klasik, uji kelayakan model dan interpretasi model. Selain itu, terdapat tiga teknik yang ditawarkan dalam regresi data panel yaitu common effect, fixed effect dan random effect (Sakti, 2018).

\subsection{Analisis Penelitian Melalui Data Panel}

Data panel dalam penelitian ini merupakan kumpulan data yang bersifat penggabungan antara cross section dan time series. Hal ini dilakukan dengan pengambilan data pada perusahaan sub sektor food \& beverages yang terdaftar di bursa efek Indonesia (BEI). Terdapat 16 perusahaan yang dapat kami teliti dikarenakan perusahaan tersebut memiliki laporan keuangan berkelanjutan dari tahun 2013-2014 secara berturut-turut. Input Data Panel pada Eviews adalah sebuah upaya pertama kali oleh para peneliti dalam melakukan analisis regresi data panel pada aplikasi eviews. Singkat cerita, agar para peneliti dapat melakukan input data ke dalam eviews untuk keperluan regresi data panel, maka para pembaca harus terlebih dahulu membuat file excel. Dimana di dalam file tersebut anda buat serangkaian data yang terdiri dari: 1) Data cross sectional, misalnya negara atau perusahaan, 2) Data runtut waktu atau time series, misalnya data dalam tahun, 3) Data variabel bebas, misalnya dalam tutorial ini kita menggunakan tiga variabel bebas, yang diberi nama $X 1, X 2$ dan $X 3$, dan 4) Data variabel terikat, misalnya dalam tutorial ini diberi nama $Y$ (A. Hidayat, 2017).

Dapat diuraikan bahwa kondisi data untuk variable Net Sales; Cost of Goods Sold; Other Expense; Income Tax Expense-Net, dan Laba Bersih dapat dilihat pada tabel berikut ini. Disajikan dalam jutaan rupiah dan merupakan data dasar eviews.

Tabel 2. Data Panel

\begin{tabular}{crrrrrr}
\hline \multirow{2}{*}{ Emiten } & Annual & $\begin{array}{c}\text { Penjualan } \\
\text { Bersih }\end{array}$ & $\begin{array}{c}\text { Beban } \\
\text { Pokok } \\
\text { Penjualan }\end{array}$ & $\begin{array}{c}\text { Beban } \\
\text { Lainnya }\end{array}$ & $\begin{array}{c}\text { Beban Pajak } \\
\text { Penghasilan } \\
\text { Bersih }\end{array}$ & $\begin{array}{c}\text { Laba } \\
\text { Bersih }\end{array}$ \\
\cline { 2 - 7 } & & (Net Sales) & $\begin{array}{c}\text { (Cost of } \\
\text { Goods Sold) }\end{array}$ & $\begin{array}{c}\text { Beban } \\
\text { Lainnya }\end{array}$ & $\begin{array}{c}\text { (Income Tax } \\
\text { Expense-Net) }\end{array}$ & (Net Profit) \\
\hline & 2013 & 55.623 .657 & 42.017 .559 & 11.264 .452 & 1.176 .600 & 4.812 .618 \\
\hline 1. Indofood Sukses & 2014 & 63.594 .452 & 46.544 .646 & 12.240 .094 & 1.828 .217 & 4.896 .782 \\
\hline Makmur Tbk (INDF) & 2015 & 47.321 .877 & 46.803 .889 & 13.754 .316 & 1.730 .371 & 4.867 .347 \\
\cline { 2 - 7 } & 2016 & 66.750 .317 & 47.321 .877 & 13.605 .676 & 2.532 .747 & 4.984 .305 \\
\hline & 2017 & 70.186 .618 & 50.416 .667 & 13.590 .649 & 2.497 .558 & 4.991 .269 \\
\hline 2. Multi Bintang & 2018 & 73.394 .728 & 53.182 .723 & 14.687 .624 & 2.485 .115 & 6.350 .788 \\
\hline
\end{tabular}




\begin{tabular}{|c|c|c|c|c|c|c|}
\hline \multirow[t]{2}{*}{ Emiten } & \multirow[t]{2}{*}{ Annual } & $\begin{array}{l}\text { Penjualan } \\
\text { Bersih }\end{array}$ & $\begin{array}{c}\text { Beban } \\
\text { Pokok } \\
\text { Penjualan }\end{array}$ & $\begin{array}{l}\text { Beban } \\
\text { Lainnya }\end{array}$ & $\begin{array}{c}\text { Beban Pajak } \\
\text { Penghasilan } \\
\text { Bersih }\end{array}$ & $\begin{array}{l}\text { Laba } \\
\text { Bersih }\end{array}$ \\
\hline & & (Net Sales) & $\begin{array}{c}\text { (Cost of } \\
\text { Goods Sold) }\end{array}$ & $\begin{array}{l}\text { Beban } \\
\text { Lainnya }\end{array}$ & $\begin{array}{c}\text { (Income Tax } \\
\text { Expense-Net) }\end{array}$ & (Net Profit) \\
\hline \multirow[t]{6}{*}{ Indonesia Tbk (MLBI) } & 2014 & 2.988 .501 & 1.182 .579 & 740.634 & 283.495 & 794.883 \\
\hline & 2015 & 2.696 .318 & 1.134 .905 & 885.841 & 178.663 & 496.909 \\
\hline & 2016 & 3.263 .311 & 1.115 .567 & 852.355 & 338.057 & 982.129 \\
\hline & 2017 & 3.389 .736 & 1.118 .032 & 725.832 & 457.953 & 1.322 .067 \\
\hline & 2018 & 3.649 .615 & 1.186 .908 & 843.624 & 447.105 & 1.224 .807 \\
\hline & 2019 & 3.711 .405 & 1.426 .351 & 680.865 & 420.553 & 1.206 .059 \\
\hline \multirow{7}{*}{$\begin{array}{l}\text { 3. Ultra Jaya Milk } \\
\text { Industry \& Trading } \\
\text { Company Tbk (ULTJ) }\end{array}$} & 2013 & 3.460 .231 & 2.446 .448 & 599.500 & 122.665 & 325.127 \\
\hline & 2014 & 3.916 .789 & 2.979 .799 & 633.168 & 112.891 & 283.360 \\
\hline & 2015 & 4.393 .932 & 3.011 .443 & 903.641 & 194.588 & 523.100 \\
\hline & 2016 & 4.685 .987 & 3.052 .883 & 777.817 & 222.657 & 709.825 \\
\hline & 2017 & 4.879 .559 & 3.056 .681 & 879.371 & 314.550 & 711.681 \\
\hline & 2018 & 5.472 .882 & 3.516 .606 & 1.084 .640 & 247.411 & 701.607 \\
\hline & 2019 & 6.241 .419 & 3.891 .701 & 1.172 .410 & 339.494 & 1.035 .865 \\
\hline \multirow{7}{*}{$\begin{array}{l}\text { 4. Akasha Wira } \\
\text { International Tbk } \\
\text { (ADES) }\end{array}$} & 2013 & 502.524 & 220.966 & 238.821 & 3.538 & 55.656 \\
\hline & 2014 & 578.784 & 279.882 & 259.347 & 10.490 & 31.021 \\
\hline & 2015 & 669.725 & 330.023 & 304.183 & 11.336 & 32.839 \\
\hline & 2016 & 887.663 & 427.828 & 401.802 & 5.685 & 55.951 \\
\hline & 2017 & 814.490 & 375.546 & 395.919 & 12.853 & 38.242 \\
\hline & 2018 & 804.302 & 415.212 & 328.791 & 17.102 & 52.958 \\
\hline & 2019 & 834.330 & 417.281 & 314.975 & 26.294 & 83.885 \\
\hline \multirow{7}{*}{$\begin{array}{l}\text { 5. Tiga Pilar Sejahtera } \\
\text { Food Tbk (AISA) }\end{array}$} & 2013 & 4.056 .735 & 3.143 .263 & 470.687 & 103.165 & 347.635 \\
\hline & 2014 & 5.139 .974 & 4.099 .240 & 596.757 & 106.381 & 377.903 \\
\hline & 2015 & 6.010 .895 & 4.737 .175 & 781.740 & 126.685 & 373.750 \\
\hline & 2016 & 6.545 .680 & 4.862 .377 & 1.080 .362 & 179.203 & 719.228 \\
\hline & 2017 & 1.950 .589 & 1.392 .462 & 5.961 .557 & 23.954 & -5.234 .288 \\
\hline & 2018 & 1.583 .265 & 1.123 .521 & 563.429 & 37.940 & -123.513 \\
\hline & 2019 & 1.510 .427 & 1.062 .970 & 983.304 & 229.689 & 1.134 .776 \\
\hline \multirow{7}{*}{$\begin{array}{l}\text { 6. Bumi Teknokultura } \\
\text { Unggul Tbk (BTEK) }\end{array}$} & 2013 & 46.980 & 42.043 & 5.617 & 54 & 2.301 \\
\hline & 2014 & 43.386 & 34.118 & 11.149 & -1.669 & 3.222 \\
\hline & 2015 & 1.092 .691 & 942.917 & 146.814 & 1.153 & 1.153 \\
\hline & 2016 & 748.088 & 638.351 & 107.557 & 92 & 2.246 \\
\hline & 2017 & 887.141 & 773.313 & 155.255 & 1.739 & 42.843 \\
\hline & 2018 & 890.045 & 809.143 & 126.474 & 1.716 & 76.001 \\
\hline & 2019 & 697.914 & 675.755 & 135.801 & 217 & 83.843 \\
\hline \multirow{7}{*}{$\begin{array}{l}\text { 7. Delta Djakarta Tbk } \\
\text { (DLTA) }\end{array}$} & 2013 & 2.001 .358 & 261.802 & 268.858 & 87.897 & 270.498 \\
\hline & 2014 & 2.111 .639 & 261.747 & 259.851 & 91.587 & 288.499 \\
\hline & 2015 & 1.573 .137 & 233.153 & 240.095 & 58.152 & 192.045 \\
\hline & 2016 & 774.968 & 234.086 & 246.863 & 72.538 & 254.509 \\
\hline & 2017 & 777.308 & 203.036 & 242.666 & 89.240 & 279.772 \\
\hline & 2018 & 893.006 & 241.721 & 254.692 & 103.118 & 338.129 \\
\hline & 2019 & 827.136 & 230.440 & 234.847 & 94.622 & 317.815 \\
\hline 8. Inti Agri Resources & 2013 & 24.844 & 36.828 & 9.800 & 5.921 & $\begin{array}{l}-18.426 \\
\end{array}$ \\
\hline
\end{tabular}




\begin{tabular}{|c|c|c|c|c|c|c|}
\hline \multirow[t]{2}{*}{ Emiten } & \multirow[t]{2}{*}{ Annual } & $\begin{array}{l}\text { Penjualan } \\
\text { Bersih }\end{array}$ & $\begin{array}{c}\text { Beban } \\
\text { Pokok } \\
\text { Penjualan }\end{array}$ & $\begin{array}{c}\text { Beban } \\
\text { Lainnya }\end{array}$ & $\begin{array}{c}\text { Beban Pajak } \\
\text { Penghasilan } \\
\text { Bersih }\end{array}$ & $\begin{array}{l}\text { Laba } \\
\text { Bersih }\end{array}$ \\
\hline & & (Net Sales) & $\begin{array}{c}\text { (Cost of } \\
\text { Goods Sold) }\end{array}$ & $\begin{array}{l}\text { Beban } \\
\text { Lainnya }\end{array}$ & $\begin{array}{c}\text { (Income Tax } \\
\text { Expense-Net) }\end{array}$ & (Net Profit) \\
\hline \multirow[t]{6}{*}{ Tbk (IIKP) } & 2014 & 21.629 & 30.839 & 8.824 & 2.965 & -11.862 \\
\hline & 2015 & 19.953 & 29.854 & 8.382 & 3.658 & -16.150 \\
\hline & 2016 & 84.354 & 95.903 & 17.100 & 4.639 & -27.568 \\
\hline & 2017 & 21.412 & 26.085 & 7.201 & 4.114 & -13.010 \\
\hline & 2018 & 17.802 & 25.735 & 8.469 & 1.802 & -15.074 \\
\hline & 2019 & 20.078 & 26.000 & 7.205 & 3.243 & 85.544 \\
\hline \multirow{7}{*}{$\begin{array}{l}\text { 9. Mayora Indah Tbk } \\
\text { (MYOR) }\end{array}$} & 2013 & 12.017 .837 & 9.096 .171 & 51.264 & 297.655 & 1.058 .418 \\
\hline & 2014 & 14.169 .088 & 11.633 .862 & 361.596 & 119.876 & 1.862 .621 \\
\hline & 2015 & 14.818 .731 & 10.620 .395 & 222.126 & 119.649 & 2.315 .242 \\
\hline & 2016 & 18.349 .960 & 13.449 .537 & 469.559 & 390.262 & 2.460 .559 \\
\hline & 2017 & 20.816 .674 & 15.841 .619 & 273.675 & 555.931 & 2.627 .892 \\
\hline & 2018 & 20.816 .674 & 17.664 .149 & 245.950 & 621.508 & 3.172 .265 \\
\hline & 2019 & 24.060 .802 & 17.109 .499 & 467.798 & 665.062 & 3.172 .265 \\
\hline \multirow{7}{*}{$\begin{array}{l}\text { 10. Sekar Laut Tbk } \\
\text { (SKLT) }\end{array}$} & 2013 & 567.048 & 442.979 & 62.870 & 6.224 & 11.440 \\
\hline & 2014 & 681.420 & 526.792 & 58.627 & 7.063 & 27.071 \\
\hline & 2015 & 745.108 & 561.186 & 68.531 & 7.309 & 33.586 \\
\hline & 2016 & 833.850 & 619.332 & 86.576 & 4.520 & 33.607 \\
\hline & 2017 & 914.189 & 677.185 & 88.442 & 4.400 & 54.166 \\
\hline & 2018 & 1.045 .030 & 777.715 & 21.490 & 7.614 & 41.294 \\
\hline & 2019 & 1.281 .116 & 957.200 & 21.413 & 11.839 & 81.240 \\
\hline \multirow{7}{*}{$\begin{array}{l}\text { 11. Sekar Bumi Tbk } \\
\text { (SKBM) }\end{array}$} & 2013 & 1.296 .618 & 1.150 .038 & 2.505 & 20.038 & 58.266 \\
\hline & 2014 & 1.480 .765 & 1.291 .253 & 43.193 & 7.063 & 1.480 .765 \\
\hline & 2015 & 1.362 .246 & 1.187 .247 & 49.070 & 30.810 & 64.529 \\
\hline & 2016 & 1.501 .116 & 1.315 .079 & 42.681 & 1.708 & 57.969 \\
\hline & 2017 & 1.841 .487 & 1.655 .322 & 7.343 & 1.659 & 51.847 \\
\hline & 2018 & 947.322 & 828.767 & 10 & 6.375 & 35.348 \\
\hline & 2019 & 19.829 & 763.450 & 2.340 & 29 & 19.829 \\
\hline \multirow{7}{*}{$\begin{array}{l}\text { 12. Tri Banyan Tirta } \\
\text { Tbk (ALTO) }\end{array}$} & 2013 & 487.200 & 347.278 & 37.375 & 7.051 & 12.058 \\
\hline & 2014 & 332.402 & 209.570 & 43.193 & 10.100 & 33.094 \\
\hline & 2015 & 301.782 & 213.328 & 49.070 & 14.772 & 9.953 \\
\hline & 2016 & 296.472 & 208.447 & 42.681 & 11.881 & 28.061 \\
\hline & 2017 & 262.144 & 220.973 & 35.731 & 68.769 & 33.998 \\
\hline & 2018 & 294.275 & 261.498 & 22.735 & 45.675 & 334.212 \\
\hline & 2019 & 343.972 & 302.040 & 30.316 & 11.090 & 7.383 \\
\hline \multirow{7}{*}{$\begin{array}{l}\text { 13. Nippon Indosari } \\
\text { Corpindo Tbk (ROTI) }\end{array}$} & 2013 & 1.505 .519 & 806.917 & 2.087 & 52.789 & 158.015 \\
\hline & 2014 & 1.880 .263 & 978.841 & 2.314 & 64.209 & 298.723 \\
\hline & 2015 & 2.174 .502 & 1.019 .511 & 2.621 & 107.713 & 453.658 \\
\hline & 2016 & 2.521 .921 & 1.220 .833 & 2.706 & 89.640 & 443.045 \\
\hline & 2017 & 2.491 .100 & 1.183 .169 & 1.452 & 50.783 & 257.165 \\
\hline & 2018 & 2.766 .546 & 1.274 .333 & 2.064 & 59.765 & 194.415 \\
\hline & 2019 & 3.337 .022 & 1.487 .586 & 5.724 & 110.580 & 356.930 \\
\hline 14. Prasidha Aneka & 2013 & 1.279 .553 & 1.103 .330 & 24.686 & 21.915 & 21.322 \\
\hline
\end{tabular}




\begin{tabular}{|c|c|c|c|c|c|c|}
\hline \multirow[t]{2}{*}{ Emiten } & \multirow[t]{2}{*}{ Annual } & $\begin{array}{l}\text { Penjualan } \\
\text { Bersih }\end{array}$ & $\begin{array}{c}\text { Beban } \\
\text { Pokok } \\
\text { Penjualan }\end{array}$ & $\begin{array}{l}\text { Beban } \\
\text { Lainnya }\end{array}$ & $\begin{array}{c}\text { Beban Pajak } \\
\text { Penghasilan } \\
\text { Bersih }\end{array}$ & $\begin{array}{l}\text { Laba } \\
\text { Bersih }\end{array}$ \\
\hline & & (Net Sales) & $\begin{array}{c}\text { (Cost of } \\
\text { Goods Sold) }\end{array}$ & $\begin{array}{c}\text { Beban } \\
\text { Lainnya }\end{array}$ & $\begin{array}{c}\text { (Income Tax } \\
\text { Expense-Net) }\end{array}$ & (Net Profit) \\
\hline \multirow[t]{6}{*}{ Niaga Tbk (PSDN) } & 2014 & 975.081 & 876.934 & 3.478 & 9.207 & 27.666 \\
\hline & 2015 & 920.353 & 813.837 & 18.495 & 9.584 & 42.620 \\
\hline & 2016 & 932.906 & 814.621 & 45 & 10.120 & 36.662 \\
\hline & 2017 & 1.399 .580 & 1.204 .487 & 2.059 & 53.562 & 70.307 \\
\hline & 2018 & 1.334 .070 & 1.187 .092 & 15.491 & 21.728 & 2.510 \\
\hline & 2019 & 1.224 .284 & 1.061 .532 & 633 & 30.104 & 33.001 \\
\hline \multirow{7}{*}{$\begin{array}{l}\text { 15. Siantar Top Tbk } \\
\text { (STTP) }\end{array}$} & 2013 & 1.283 .736 & 1.036 .609 & 12.891 & 18.490 & 74.626 \\
\hline & 2014 & 2.170 .464 & 1.763 .078 & 16.437 & 167.978 & 123.636 \\
\hline & 2015 & 2.544 .278 & 2.012 .271 & 17.446 & 232.005 & 185.705 \\
\hline & 2016 & 2.629 .107 & 2.079 .869 & 6.344 & 217.746 & 174.177 \\
\hline & 2017 & 2.825 .409 & 2.211 .949 & 28.776 & 288.546 & 216.024 \\
\hline & 2018 & 2.826 .957 & 2.207 .269 & 20.956 & 324.695 & 255.089 \\
\hline & 2019 & 3.512 .509 & 2.559 .476 & 52.042 & 607.043 & 482.591 \\
\hline \multirow{7}{*}{$\begin{array}{l}\text { 16. PT. Indofood CBP } \\
\text { Sukses Makmur Tbk } \\
\text { (ICBP) }\end{array}$} & 2013 & 25.094 .681 & 18.668 .990 & 262.720 & 733.699 & 2.235 .040 \\
\hline & 2014 & 30.022 .463 & 21.922 .158 & 157.251 & 871.208 & 3.185 .348 \\
\hline & 2015 & 31.741 .094 & 22.121 .957 & 187.244 & 1.086 .486 & 3.992 .132 \\
\hline & 2016 & 34.466 .069 & 23.606 .755 & 382.581 & 1.357 .953 & 4.864 .168 \\
\hline & 2017 & 35.606 .593 & 24.547 .757 & 564.926 & 1.663 .388 & 5.221 .746 \\
\hline & 2018 & 38.413 .407 & 26.147 .857 & 143.012 & 1.788 .004 & 6.447 .921 \\
\hline & 2019 & 42.296 .703 & 27.892 .690 & 312.282 & 2.076 .943 & 7.400 .117 \\
\hline
\end{tabular}

Sumber: Hasil Pengolahan Data (2020)

\subsection{Tahapan Regresi Data Panel}

Dalam pemilihan model regresi, peneliti menggunakan pemodelan data panel yang bersifat cross section dan data time series. Hal ini dimaksud agar pengolahan data dapat dilakukan dengan mudah dalam proses olah data dengan menggunakan aplikasi program eviews.

Estimasi model regresi data panel bertujuan untuk memprediksi parameter model regresi yaitu nilai intersep atau konstanta $(\alpha)$ dan slope atau koefisien regresi $(\beta i)$. Penggunaan data panel dalam regresi akan menghasilkan intersep dan slope yang berbeda pada setiap perusahaan dan setiap periode waktu. Untuk mengestimasi parameter model dengan data panel, terdapat tiga teknik yang ditawarkan yaitu: 1) Model common effect (CEM), 2) Model fixed effect (FEM), dan 3) Model random effect (REM). Kemudian, Terdapat tiga uji untuk memilih teknik estimasi data panel yaitu uji chow (uji statistik F), uji hausman dan uji lagrange multiplie (Sakti, 2018).

\subsection{Pemodelan dan Uji Asumsi Klasik}

Regresi linear Ordinary Least Square (OLS) merupakan uji statistik yang sangat popular di kalangan mahasiswa, terutama mahasiswa yang kuliah dengan di bidang ekonomi atau akuntansi. Uji regresi linear ini dapat diuji menggunakan beberapa jenis software statistik yang 
mana salah satunya adalah eviews. Maka untuk memenuhi tuntutan mahasiswa itulah, statistikian coba untuk membuat artikel tentang tutorial uji regresi linear dengan eviews (A. Hidayat, 2017).

Berdasarkan uraian di atas, jika model yang terpilih ialah common effect atau fixed effect maka uji asumsi klasik yang harus dilakukan meliputi uji heterokedastisitas dan uji multikolinearitas. Sedangkan jika model yang terpilih berupa random effect maka tidak perlu dilakukan uji asumsi klasik. Meskipun demikian, lebih baik uji asumsi klasik berupa uji normalitas, autokorelasi, heteroskedastisitas dan multikolinieritas tetap dilakukan pada model apapun yang terpilih dengan tujuan untuk mengetahui apakah model yang terbentuk memenuhi syarat BLUE (Best Linier Unbias Estimator) (Sakti, 2018). Uji Asumsi Klasik dimaksud adalah; 1) Uji Normalitas, 2) Uji Auto Korelasi, 3) Uji Heteros Kedastisitas, dan 4) Uji Multiklolinieritas. Adapun untuk uji kelayakan model, dilakukan uji hipotesis dengan cara uji t dan uji f serta koefisien determinasinya.

\subsection{Hasil Uji Uji Chow}

Dapat diketahui secara umum, bahwa: Persamaan regresi adalah $y=c(1)+c(2)^{*} x$ atau dalam aplikasi program eviews = y x1 x2 ×3 x4 c kemudian dapat dirubah menjadi y c x1 x2 ×3 x4. Tahapan langkah tersebut dapat digunakan untuk metode Common effect Metode (CEM) atau Fixed effect Metode (FEM). Dan perbedaannya terdapat pada panel option.

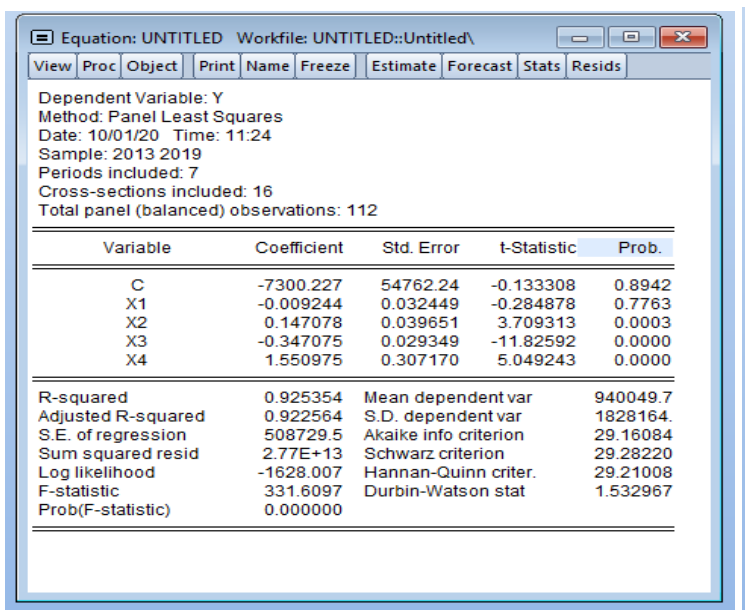

Sumber: Hasil Pengolahan Data (2020)

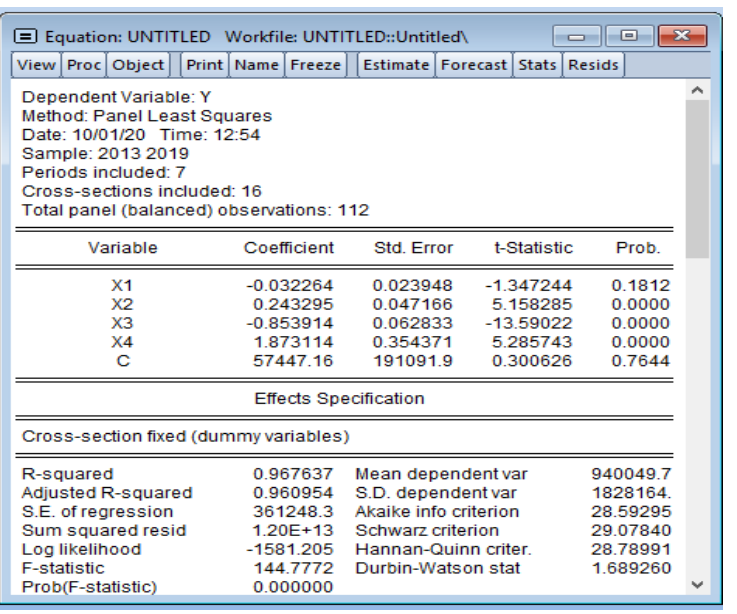

Gambar 2. Pemodelan Metode CEM dan FEM

Gambar 2 diketahui untuk mengetahui pemodelan dengan bersandar kepada nilai probabilitas, untuk metode CEM sebesar 0.8942, sedangkan untuk metode FEM sebesar 0.1812. Hal ini dapat diketahui bahwa nilai probabilitas CEM C>0.05) sedangkan FEM $\mathrm{C}<0.05$ ). Sehingga untuk kemudian dapat kita tentukan melalui uji chow. 


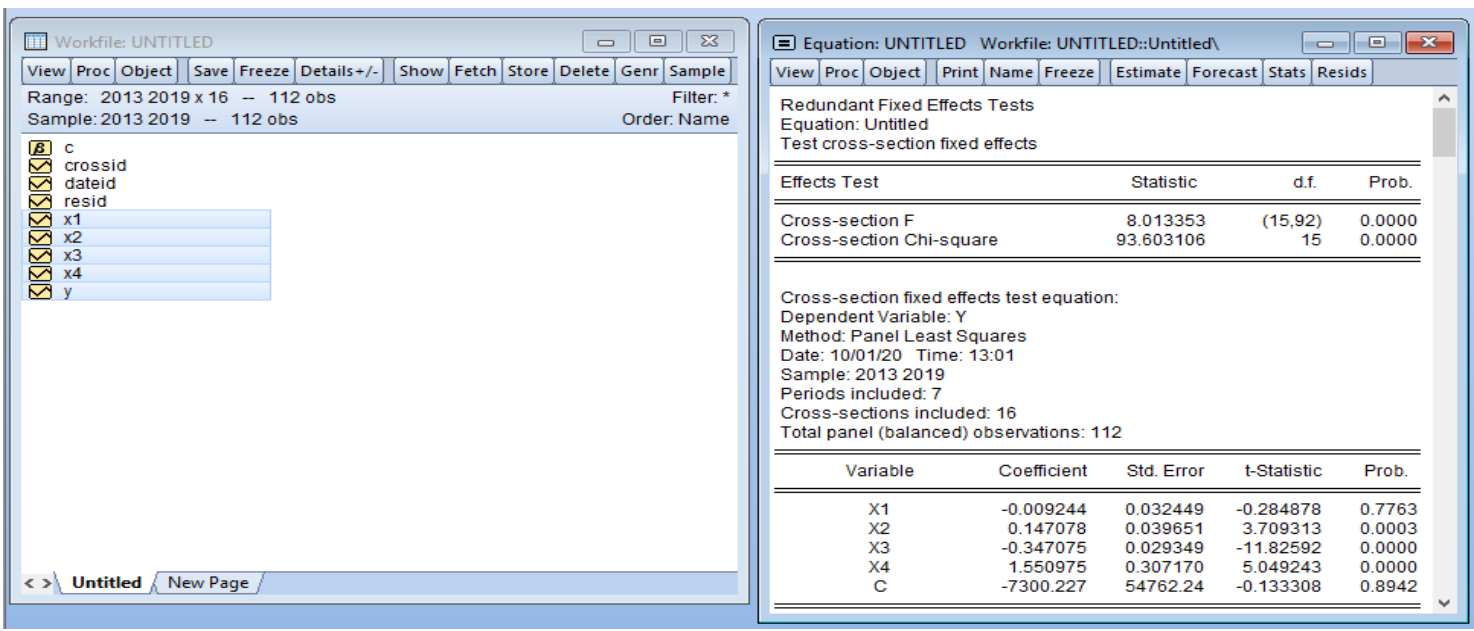

Sumber: Hasil Pengolahan Data (2020)

\section{Gambar 3. Uji Chow Dengan Pemodelan CEM dan FEM}

Dari gambar uji Chow diketahui nilai probabilitasnya 0.0000 lebih kecil dari 0.05 yang artinya model FEM yang sebaiknya dipilih.

\subsection{Hasil Uji Hausman dengan REM dan FEM}

Setelah mendapatkan pilihan dengan pemodelan FEM, maka tahapan selanjutnya adalah melakukan uji hausman untuk membandingkan mana yang terbaik antara FEM atau REM. Gambar 4 merupakan hasil uji hausman dengan pemodelan REM.

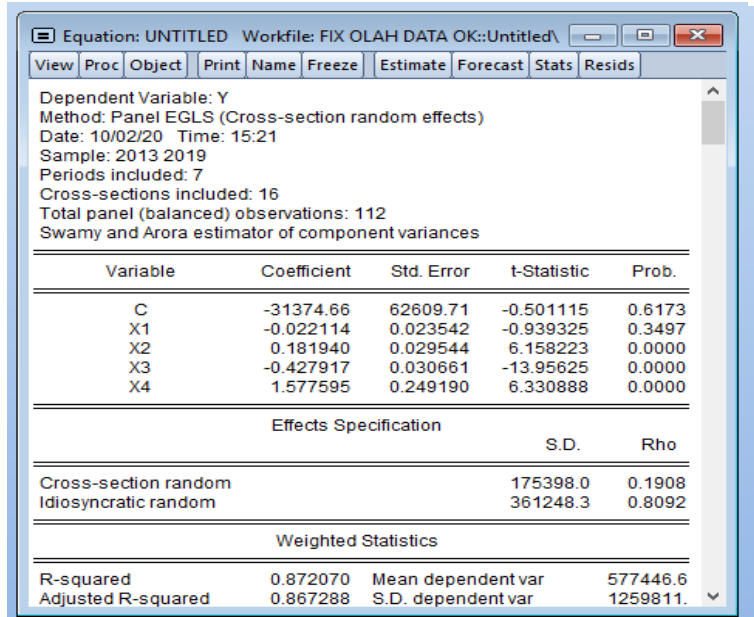

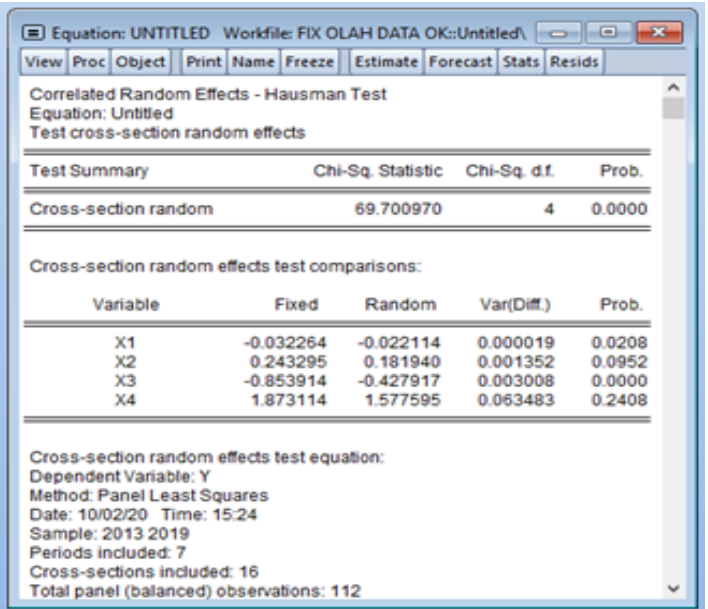

Sumber: Hasil Pengolahan Data (2020)

Gambar 4. Pemodelan dengan metode REM dan hasil Uji Hausman untuk metode REM

Pada tersebut tertulis cross section random, yang artinya pengujian uji hausman sudah dilakukan. Dan gambar diatas menunjukkan hasil uji dengan nilai probabilitasnya 0,0000 yang artiny lebih kecil dari 0.05 . Sehingga jika dibandingkaan antara REM dan FEM yang terbaik untuk dipilih adalah FEM. Dan selanjutnya, kita dapat melanjutkannya ke uji asumsi klasik.

\subsection{Hasil Uji Asumsi Klasik}

Uji Asumsi Klasik disini meliputi; uji normalitas, uji multikolilnieritas, uji heteroskedastisitas, dan uji auto korelasi yang dapat ditampilkan dalam gambar berikut. 


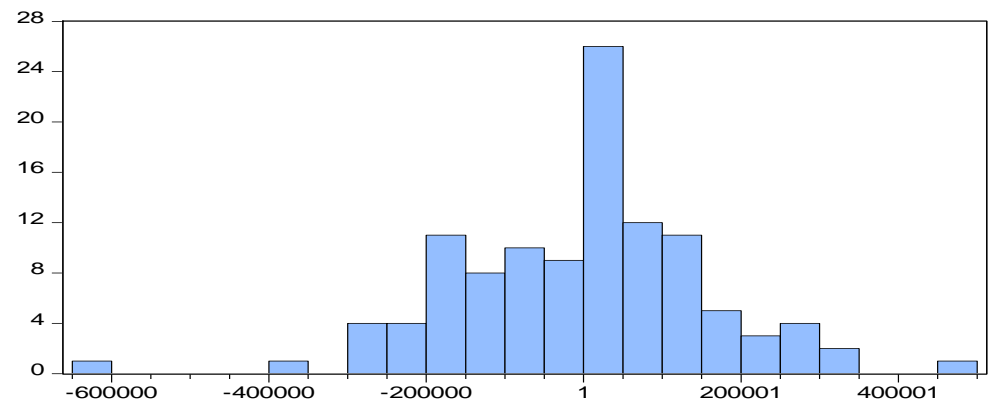

\begin{tabular}{|c|c|}
\hline \multicolumn{2}{|c|}{$\begin{array}{l}\text { Series: Standardized Residuals } \\
\text { Sample } 20132019 \\
\text { Observations } 112\end{array}$} \\
\hline Mean & $-4.96 e-11$ \\
\hline Median & 20714.01 \\
\hline Maximum & 459670.8 \\
\hline Minimum & -634518.9 \\
\hline Std. Dev. & 158977.5 \\
\hline Skewness & -0.346498 \\
\hline Kurtosis & 4.608119 \\
\hline Jarque-Bera & 14.30936 \\
\hline Probability & 0.000781 \\
\hline
\end{tabular}

Sumber: Hasil Pengolahan Data (2020)

Gambar 5. Uji Asumsi Klasik dengan pendekatan Uji Normalitas

Pada data gambar 5 terlihat nilai Jarque-Beranya sebesar 14.30936, sedangkan untuk nilai probabilitasnya sebesar 0.000781 . yang artinya, nilai probabilitas tersebut berada dibawah 0.05. sehingga dikatakan data tidak terdistribusi normal.

Analisis regresi selain pemodelan dan mengetahui variabel penyebab yang signifikan, ada hal yang lain ketika peneliti menghendaki fungsi penaksiran dari model yaitu pengujian asumsi regresi linear klasik. Untuk menguji normalitas pada residual (resid), klik menu View, Descriptive Statistics pilih Histogram and Stats, maka akan tampilan jendela Eviews sebagai berikut. (Uji normalitas pada Eviews secara satu per satu (dengan histogram) (Richie, 2020).
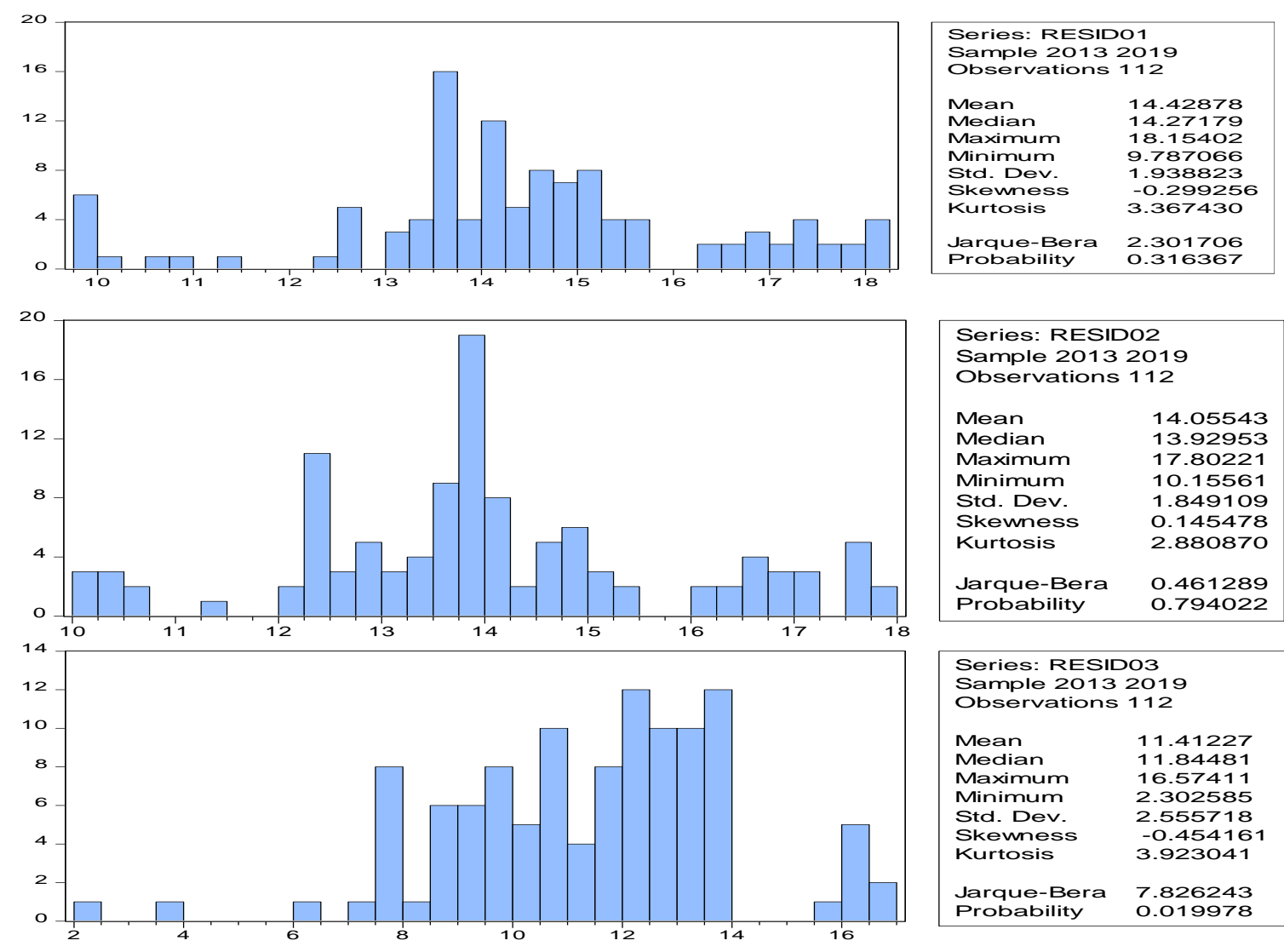

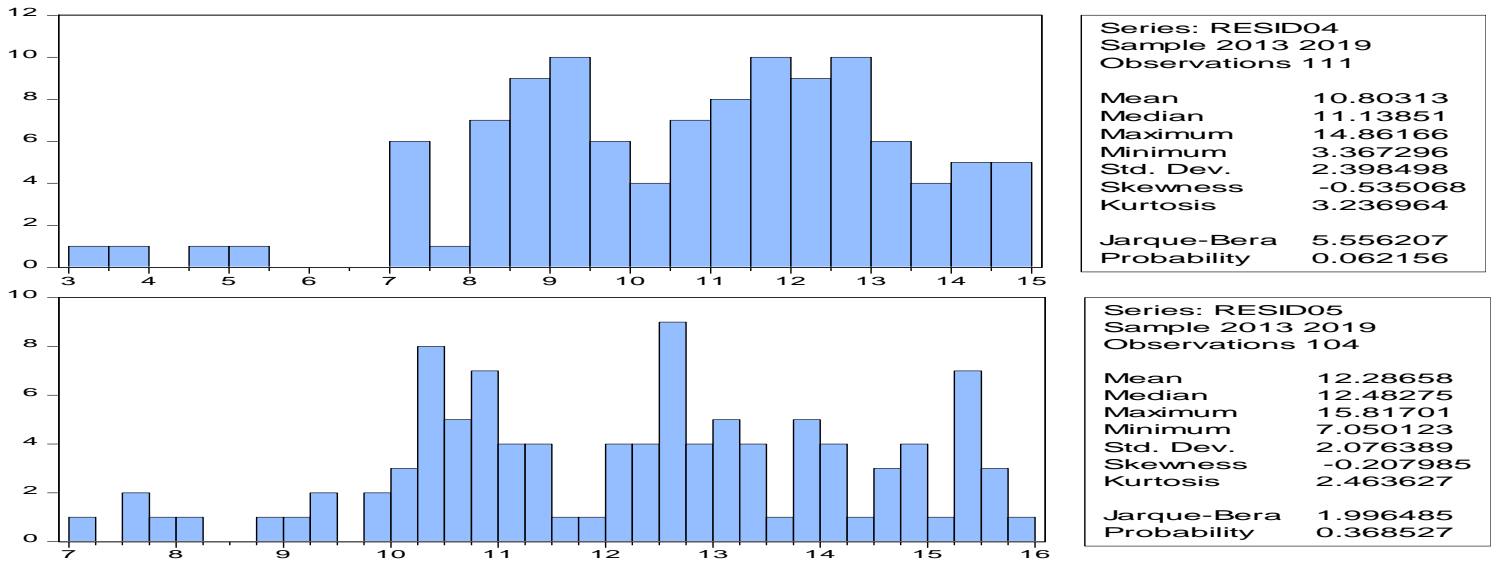

Sumber: Hasil Pengolahan Data (2020)

Gambar 5. Uji Normalitas Pervariabel

Setelah melakukan uji normalitas per variabel, didapat keseluruah variabel terdistribusi normal, terkecuali untuk variabel beban lainnya yang tidak terdistribusi dengan normal. Pada gambar resid03 untuk variabel Beban Lainnya (Other Expense) dengan nilai probabilitasnya sebesar 0,019978, yang berarti kurang dari 0,05. Selanjutnya adalah melakukan uji multikolilnieritas. Berikut tabel uji multikolilnieritas.

Tabel 3. Hasil Uji Multikolilnieritas

\begin{tabular}{lcccc}
\hline Resid01 & Resid01 & Resid02 & Resid03 & Resid04 \\
\cline { 2 - 4 } & \multicolumn{1}{l}{ Resid020.9528191632798878 } & \multicolumn{1}{l}{0.95281916327988780 .56136698391871080 .8157321900239935} \\
\hline
\end{tabular}

Sumber: Hasil Pengolahan Data (2020)

Tabel 3 menunjukkan tidak terdapat multikoliniearitas. Hal ini dapat dilihat dari dari nilai antar variabel Resid01 (Penjualan Bersih) $=0.5613669839187108$, variabel Resid02 (Beban Pokok Penjualan) $=0.5007998533675093$, variabel Resid03 (Beban Lainnya) $=$ 0.5007998533675093, variabel Resid04 (Beban Pajak Bersih) $=0.5143260510838168$, kurang dari 0.8. dan artinya dalam Uji Multikolinearitas disini tidak terdapat. Selanjutnya adalah melakukan uji heterokedastisitas pada gambar berikut.

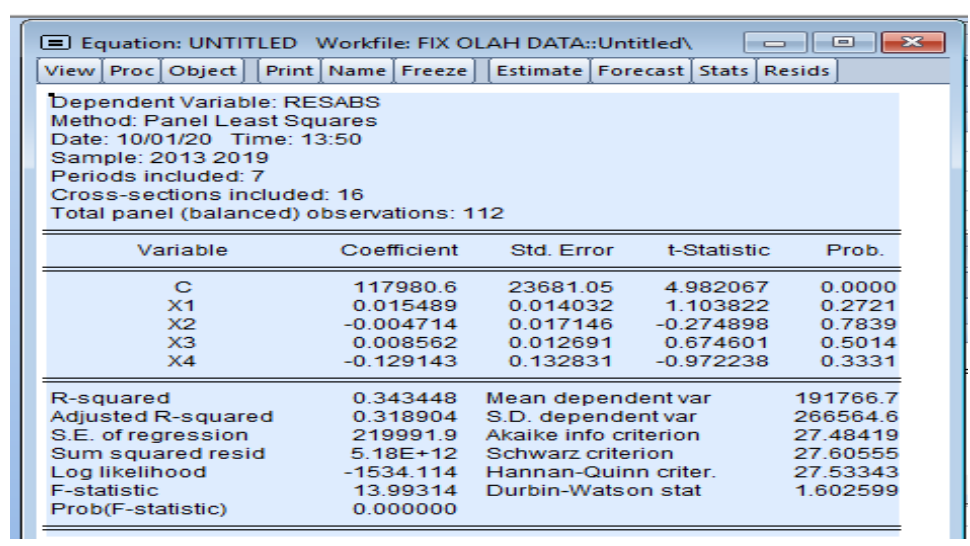

Sumber: Hasil Pengolahan Data (2020)

Gambar 6. Uji Heterokedastisitas 
Untuk uji heterokedastisitas didapat nilai probabilitasnya dari masing-masing variable $\mathrm{X} 1=0.2721, \mathrm{X} 2=0.7839, \mathrm{X} 3=0.5014, \mathrm{X} 4=0.3331$ yang artinya jika dibandingkan dengan derajat kealphaan 0.05. maka dapat disimpulkan tidak terjadi heterokedastisitas, karena masingmasing variabel melebihi porsentase alpha. Sehingga dapat dikatakan layak uji asumsi klasik.

Dan pada akhirnya masuk ketahapan uji auto korelasi yang dapat dilihat melalui tabel berikut.

Tabel 4. Hasil Uji Heterokedastisiitas

Dependent Variable: $Y$

Method: Panel EGLS (Cross-section random effects)

Date: 10/01/20 Time: 13:54

Sample: 20132019

Periods included: 7

Cross-sections included: 16

Total panel (balanced) observations: 112

Swamy and Arora estimator of component variances

\begin{tabular}{ccccc}
\hline \hline Variable & Coefficient & Std. Error & t-Statistic & Prob. \\
\hline \hline X1 & -0.022114 & 0.023542 & -0.939325 & 0.3497 \\
X2 & 0.181940 & 0.029544 & 6.158223 & 0.0000 \\
X3 & -0.427917 & 0.030661 & -13.95625 & 0.0000 \\
X4 & 1.577595 & 0.249190 & 6.330888 & 0.0000 \\
C & -31374.66 & 62609.71 & -0.501115 & 0.6173 \\
& & & & \\
& \multirow{2}{*}{ Effects Specification } & S.D. & Rho \\
\hline \hline & & & 175398.0 & 0.1908 \\
Cross-section random & & 361248.3 & 0.8092 \\
Idiosyncratic random & & & \\
\hline \hline
\end{tabular}

\begin{tabular}{llll}
\hline \hline \multicolumn{4}{l}{ Weighted Statistics } \\
\hline \hline R-squared & 0.872070 & Mean dependent var & 577446.6 \\
Adjusted R-squared & 0.867288 & S.D. dependent var & 1259811. \\
S.E. of regression & 458945.8 & Sum squared resid & $2.25 \mathrm{E}+13$ \\
F-statistic & 182.3487 & Durbin-Watson stat & 1.583706 \\
Prob(F-statistic) & 0.000000 & & \\
\hline \hline & Unweighted Statistics & \\
\hline \hline R-squared & 0.919989 & Mean dependent var & \\
Sum squared resid & $2.97 \mathrm{E}+13$ & Durbin-Watson stat & 1.202474 \\
\hline \hline
\end{tabular}

Sumber: Hasil Pengolahan Data (2020)

Dari tabel 4 secara parsial uji hipotesis untuk Penjualan Bersih ( $x 1$ ) tidak memiliki pengaruh karena memiliki nilai probabilitas sebesar 0.3497, untuk Beban Pokok Penjualan (x2) memiliki pengaruh karena memiliki nilai probabilitas sebesar 0.000 , untuk Beban Lainnya ( $x 3$ ) memiliki pengaruh karena memiliki nilai probabilitas sebesar 0.000 , dan untuk Beban Pajak 
Bersih (x4) memiliki pengaruh karena memiliki nilai probabilitas sebesar 0.000. Sedangkan secara simultan, Penjualan Bersih (x1), Beban Pokok Penjualan (x2), Beban Lainnya (x3), Beban Pajak Bersih ( $x 4$ ) mempunyai pengaruh. Hal ini dapat dilihat pada tabel diatas yang menunjukkan Prob F-statistiknya sebesara 0.000000.

Maka selanjutnya untuk persamaan regresinya dengan rumus adalah $y=c(1)+c(2)^{*} x$ atau $y=c+$ Penjualan Bersih (x1) + Beban Pokok Penjualan (x2) + Beban Lainnya (x3) + Beban Pajak Bersih (x4).

$$
\begin{aligned}
& Y=-31374.66+(-0.022114)+0.18194+(-0.427917)+1.577595 \\
& Y=-31373.350496
\end{aligned}
$$

\section{Kesimpulan}

Dari kegiatan pemodelan CEM, FEM, dan REM, serta dengan tahapan proses uji Chow, uji Hausman, dan Uji Asusmsi klasik. Peneliti memahami banyak proses yang kemudian dapat disimpulkan bahwa antar variabel yang telah diuji melalui uji normalitas, uji multikolinieritas, uji heterokedastisitas, dan uji hipotesis didapat perbedaan dengan peneliti sebelumnya yang menyatakan tidak ada pengaruhnya, terhadap variabelnya dan berpengaruh secara simultan pada variabel keseluruhan. Namun pada penelitian ini secara keseluruhan memiliki pengaruhnya, dan secara parsial hanya variabel penjualan bersih yang tidak memiliki pengaruh.

\section{Ucapan Terima Kasih (Opsional)}

Terimakasih kepada semua pihak yang membantu proses penyusunan artikel ini terutama pihak Kemenristekdikti yang telah memberikan dukungan material melalui Pendanaan HIBAH PDP Tahun 2020 dan LPPMP Universitas Bhayangkara Jakarta Raya, serta pihak lainnya yang telah memberikan dukungan materil maupun non materil.

\section{Daftar Pustaka}

Andhika. (2020). Daftar Perusahaan Food and Beverage yang Daftar Perusahaan Food and Beverage yang Terdaftar di BEl. Retrieved from https://ajaib.co.id/daftar-perusahaan-foodand-beverage-yang-terdaftar-di-bei/

Aprillia Susanti. (2018). Pengaruh Pengalaman Kerja Dan Kompetensi Auditor Terhadap Kualitas Audit Pada PT BPR Karya Guna Mandiri Bandung. Jurnal Akuntansi, Audit Dan Sistem Informasi Akiuntansi (JASa), 2(4). Retrieved from https://media.neliti.com/media/publications/284366-pengaruh-pengalaman-kerja-dankompetensi-528c4c4e.pdf

Hapsari, D. P., \& Saputra, A. (2018). Analisis Penjualan Bersih, Beban Umum \& Administrasi Terhadap Laba Tahun Berjalan. Jurnal Akuntansi : Kajian Ilmiah Akuntansi (JAK), 5(1), 45. https://doi.org/10.30656/jak.v5i1.502

Hidayat, A. (2017). Cara Membaca Hasil Regresi Data Panel Dengan Eviews. Retrieved from 
https://www.statistikian.com/2017/03/tutorial-cara-input-data-panel-dengan-eviews.html Hidayat, W. W., Purnomo, A. I., \& Ulfah, A. (2016). Determinan Pajak Penghasilan Terutang (Studi Kasus : Pada Perusahaan Manufaktur Yang Terdaftar di Bursa Efek), 12(2), 20-24. Husadha, C., Zen, A., \& Panjaitan, E. (2014). Pengaruh Penjualan Bersih, Beban Pokok Penjualan, Dan Beban Usaha Lainnya Atas Output Laba Bersih PT. Indofood Sukses Makmur Tbk. Jurnal Ilmiah Akuntansi Dan Manajemen, 10(2), 8-21.

Kurniawan, R., Hidayati, K., \& Cholifah. (2016). Pengaruh Penjualan Dan Harga Pokok Penjualan Terhadap Perubahan Laba Kotor Pada PT. Indocement Tunggal Prakarsa, Tbk, 61-70.

Mahmudah, W., Suryati, A., \& Husadha, C. (2019). Perencanaan Pajak Dan Beban Pajak Tangguhan Atas Persistensi Laba Perusahaan Manufaktur Di BEl. Jurnal Ilmiah Akuntansi Dan Manajemen, 15, No.1, 29-37.

Nurlita, R. R., Nugroho, T. R., \& Ainiyah, N. (2017). Pengaruh Laba Kotor, Laba Operasi Dan Laba Bersih Untuk Memprediksi Arus Kas Masa Depan Pada Perusahaan Food \& beverages Yang Terdaftar Di Bei Periode 2015 - 2017. Fakultas Ekonomi, Universitas Islam Majapahit.

Richie. (2020). Asumsi Normalitas Dengan Eviews. Retrieved from https://www.mobilestatistik.com/asumsi-normalitas-dengan-eviews

Sakti, I. (2018). Tutorial Regresi Data Panel dengan Eviews 9. Retrieved from https://catatanis.wordpress.com/2018/07/17/tutorial-regresi-data-panel-dengan-eviews-9bagian-1/

Satwika, F., Hendratno, \& Zultilisna, D. (2018). Pengaruh Harga Pokok Produksi, Biaya Operasional, Dan Penjualan Bersih Terhadap Laba Bersih (Studi Kasus pada Perusahaan Sektor Industri Tekstil dan Garmen yang Terdaftar di Bursa Efek Indonesia Tahun 20122016). E-Proceeding of Management, 5, No.2, 2154-2162. Retrieved from http://dx.doi.org/10.1016/j.biotechadv.2010.07.003\%0Ahttp://dx.doi.org/10.1016/j.scitotenv .2016.06.080\%0Ahttp://dx.doi.org/10.1016/j.bbapap.2013.06.007\%0Ahttps://www.frontiersi n.org/article/10.3389/fmicb.2018.02309/full\%0Ahttp://dx.doi.org/10.1007/s13762-

www.pelajaran.co.id. (2019). Pengertian Perusahaan Dagang: Ciri, Akun, Jenis, Kegiatan dan Contohnya. Retrieved from https://www.pelajaran.co.id/2019/03/perusahaan-dagang.html 